\title{
Demand for Life Insurance-An Empirical Analysis in the Case of Poland
}

\author{
Adam Sliwinski, Tomasz Michalski and Malgorzata Roszkiewicz \\ Warsaw School of Economics, Al. Niepodleglosci 162, Poland. \\ E-mails: asliwin@sgh.waw.pl; tomich@sgh.waw.pl; mroszki@sgh.waw.pl
}

This paper presents the results of a study of the determination of life insurance demand in Poland. A characterisation of the Polish life insurance sector is given, including a comparison with the top ten emerging markets and other CEE countries such as Hungary and the Czech Republic. The characterisation is followed by a review of the previous studies of life insurance determinants. Subsequently, factor analysis is applied to distinguish independent factors that determine demand for life insurance. Then a linear regression model is used to identify both the factors that have determined life insurance in Poland and the extent thereof. However, as opposed to previous studies of life insurance demand, only distinguished factors are used as an independent variable. The study confirms that factors of an economic and financial nature strongly stimulate the demand for life insurance, which agrees with previous studies. However, some results contradict the previous findings such as the factor that includes variables such as education level and social benefits.

The Geneva Papers (2013) 38, 62-87. doi:10.1057/gpp.2012.21

Keywords: life insurance; demand; factor analysis; principal components method; emerging markets

Article submitted 24 January 2011; accepted 7 March 2012; published online 11 July 2012

\section{Introduction}

Life insurance demand is the subject of a number of research projects. Nevertheless, the majority of studies focus on types of determinants and the extent of determination on the level of insurance consumption. The studies use a set of variables. However, after careful analysis, we can conclude that the process of choosing variables is not effective enough. The variables are used rather more intuitively. In addition to that, researchers estimate previous models using data from different countries or various time periods. Furthermore, there is also a lack of research into the life insurance demand determinants with regard to Central and Eastern Europe (CEE). This part of the world has undergone a significant economic change over the course of the last decade. Presently, the financial sector in countries such as Poland plays a crucial role in the creation of overall macroeconomic development and capital flow in the region. The economic processes that Poland has witnessed in recent years have also affected the broad insurance sector. The social and economic transformations, the break-up of monopolies and growing competition have contributed to the development of business insurance. This, in turn, can be illustrated both by growing numbers of entities offering insurance products on the Polish market and by the increase in the written 
premium. During the transformation, the total life insurance market gross written premium rose by 36 per cent annually.

Despite such impressive growth, the Polish insurance sector still lags considerably behind western economies. While the Polish insurance market is generally believed to be in the growth stage, this market is of particular significance given the integration of Poland with the economic system of the European Union (EU). EU integration and the advancing globalisation of financial services create a need for ongoing monitoring and a revision of the current operating strategies, notably with regard to their financial aspect. The continuing development of the insurance sector is in the interest of insurance companies operating in Poland. Insurance companies should seek to optimise their financial performance and improve the flexibility of their insurance services so that they can contribute to improving the financial standing of insured businesses and households as well. This can be made possible by an ongoing search for factors that will improve the competitiveness of businesses and by raising the insurance awareness of the general public, which, undoubtedly, poses a great challenge. One of the success factors is acquiring the ability to combine the efforts of the management teams of insurance companies with research findings. However, one has to take into account the fact that dynamic expansion has generated strong market competition. Consequently, insurance companies should continuously look for new comprehensive solutions in order to maximise their profits. One of the main factors that has influenced their overall performance is consumption level. The higher the level of aggregated consumption, the better the insurance sector develops. A full understanding of demand behaviour is needed by managers to optimise the level of sales. From the scientific point of view, recognition of significant insurance demand features is also of utmost importance. As pointed out earlier, no studies concerning the demand for life insurance in CEE, especially in Poland, have been conducted thus far. Since Poland has developed one of the largest life insurance markets among all the CEE countries, we find it reasonable to use Poland as the basis for our research.

The main aim of this work is to present the results of the study on the determination of life insurance demand in Poland. The subject and the findings are equally very important from the business sector perspectives and from the point of view of insurance theory. At the beginning of the paper, a short characterisation of the Polish life insurance sector is presented, including a comparison with other world emerging markets and selected CEE countries, such as Hungary, Bulgaria, Romania, Ukraine and the Czech Republic. This outline is followed by a review of the previous studies of life insurance determinants. A successive empirical part is then provided. The research is based on the set of preliminary variables. Necessary variables have been identified after studying the literature on the subject. Then, the study applies factor analysis to a process of distinguishing the independent factors, which determine demand for life insurance. In the final part of the paper, a linear regression model is used. The model describes a relationship between life insurance demand and the distinguished factors. However, in the regression model, as opposed to a previous study of life insurance demand, only distinguished factors are used as an independent variable. The change of gross premium written represents a dependent variable. The paper ends with the conclusions presenting the results of the empirical exercises, followed by a comparison of the findings with the previous studies. 


\section{Characteristics of the Polish life insurance market}

The Polish insurance market is still regarded as an emerging market. When we compare it with mature western European markets, such as Great Britain, we can assume that the Polish market is rather small. The total number of operating companies is 63 , including life insurance and general insurance companies. However, during the last 19 years of development, the Polish insurance market has witnessed two ground-breaking events, which undoubtedly have had a significant impact on the market's shape and performance.

First, a new insurance act was implemented in July 1990, with the primary aim of allowing private and foreign investors to invest in the Polish insurance market. Since 1990, they have been able to open insurance companies. The market was dominated by two main State-owned insurance companies (PZU and Warta). July 1990 is considered the starting point in the process of creating the new free Polish insurance market.

The access of Poland to the EU, which took place in May 2004, was another ground-breaking event that ultimately opened up the Polish market. At present, according to the three main integration pillars included in the Treaty of Rome, European companies may open branches or subsidiaries in Poland without any permission or any licence from the Insurance Supervision Committee. Despite this, the market is still rather small, yet these two important events and the time of transition allow us to do the research.

On the other hand, the Polish insurance market is one of the biggest among other emerging markets. It holds a top-ranked position with regard to the gross written premium's share in total gross written premium among all emerging markets. According to the data published by Swiss Re, Poland is ranked the sixth emerging market in terms of gross written premium in life business and eighth in terms of nonlife business. As for life insurance, China, India, Taiwan, South Africa and Brazil have a higher share than Poland. In the case of non-life business, Poland ranks immediately after South Africa, with the share of 4.2 per cent of total gross written premium. The breakdown of insurance gross written premium according to the emerging markets is shown in Table 1.

The Polish insurance market has developed gradually. Over the course of the last ten years, the life gross written premium has increased five-and-a-half-fold. As shown above, the market reached the middle position among other ten top emerging markets. The evolution of the Polish life insurance market from 2000 to 2010 is presented in Figure 1. The visible change in the level of gross written premium in 2008 was a direct cause of the financial crisis. A dynamic growth in contributions that year was due to the downfall of the stockmarket and a dwindling trust in banks and investment funds. The customers wrote off equity units in investment funds and then part of their savings (capital) moved to the insurance sector by purchasing insurance with a guaranteed sum of insurance (whole life insurance). However, in 2009, as the stockmarket stabilised, some customers returned to invest more aggressively, by cashing-in existing polices and providing funds to purchase units of investment funds.

The Polish life insurance market is also the biggest among other CEE countries in the region. The market gross written premium comprises 0.36 per cent of the entire worldwide life insurance market. Next is the market in the Czech Republic with 
Table 1 Top ten emerging markets in life and non-life insurance

\begin{tabular}{lcclcr}
\hline $\begin{array}{l}\text { Life } \\
\text { insurance }\end{array}$ & $\begin{array}{c}\text { 2010 premium volume } \\
\text { (in million USD) }\end{array}$ & $\begin{array}{c}\text { Share of } \\
\text { emerging } \\
\text { markets }(\%)\end{array}$ & $\begin{array}{l}\text { Non-life } \\
\text { insurance }\end{array}$ & $\begin{array}{c}\text { 2010 premium volume } \\
\text { in million USD) }\end{array}$ & $\begin{array}{c}\text { Share of } \\
\text { emerging } \\
\text { markets }(\%)\end{array}$ \\
\hline China & 142,999 & 36.4 & China & 71,628 & 33.9 \\
India & 67,810 & 17.3 & Russia & 40,742 & 19.3 \\
Taiwan & 63,920 & 16.3 & Brazil & 30,847 & 14.6 \\
South Africa & 43,186 & 11.0 & Taiwan & 12,505 & 5.9 \\
Brazil & 33,246 & 8.5 & India & 10,565 & 5.0 \\
Poland & $\mathbf{8 , 9 7 7}$ & $\mathbf{2 . 3}$ & Mexico & 10,250 & 4.9 \\
Mexico & 8,945 & 2.3 & South Africa & 10,111 & 4.8 \\
Thailand & 8,313 & 2.1 & Poland & $\mathbf{8 , 7 8 6}$ & $\mathbf{4 . 2}$ \\
Malaysia & 7,910 & 2.0 & Venezuela & 7,851 & 3.7 \\
Indonesia & 7,202 & 1.8 & Turkey & 7,786 & 3.7 \\
Top 10 & 392,508 & 100.0 & Top 10 & 211,071 & 100.0
\end{tabular}

Source: Authors based on data published by Swiss Re, Sigma 2/2011 (pp. 35-37).

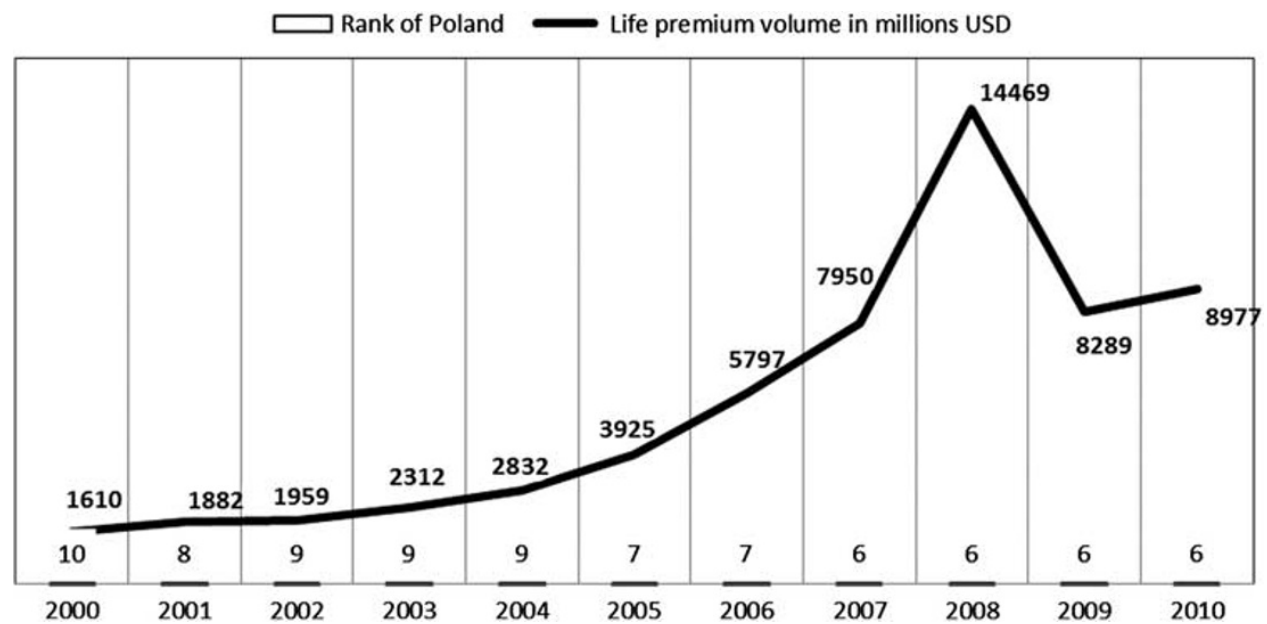

Figure 1. Evolution of the Polish life insurance market 2000-2010. Source: Based on data published by Swiss $\operatorname{Re}^{23}$ (www.swissre.com/sigma/).

0.15 per cent of the total world's premium. Life insurance business exceeds 50 per cent of the total Polish insurance market. A similar situation among the CEE countries exists only in Hungary, where the life insurance premium accounts for 53.5 per cent. The breakdown of life insurance gross written premium in selected post-communist countries is shown in Table 2.

The fact that the Polish market is still one of the largest markets among other emerging and post-communist countries also gives us a good reason for studying it. On the other hand, during the transition period, the Polish insurance market underwent significant changes. What changed most was ownership structure. For example, 
Table 2 Life insurance market in chosen CEE countries

\begin{tabular}{lcccc}
\hline Country & $\begin{array}{c}\text { Life premium volume } \\
\text { (in million USD) }\end{array}$ & $\begin{array}{c}\text { Share of total } \\
\text { business in the country (\%) }\end{array}$ & $\begin{array}{c}\text { Share of world's } \\
\text { market 2010 (\%) }\end{array}$ \\
\cline { 2 - 3 } & 2010 & 2009 & & \\
\hline Poland & 8,977 & 8,290 & 50.5 & 0.36 \\
Czech Republic & 3,694 & 3,160 & 46.7 & 0.15 \\
Hungary & 2,137 & 2,029 & 53.5 & 0.08 \\
Romania & 515 & 524 & 19.6 & 0.02 \\
Bulgaria & 138 & 142 & 12.0 & 0.01 \\
Ukraine & 102 & 106 & 4.1 & 0.00 \\
Total Europe & 965,661 & 953,418 & 59.6 & 38.32 \\
\hline
\end{tabular}

Source: Authors based on data published by Swiss Re, Sigma 2/2011 (p. 35).

domestic capital made up 75 per cent of the entire subscribed capital in 1991. During the period of transition (to 2008), domestic capital decreased to only 23 per cent. This decrease in domestic capital level was gradual. Nevertheless, we can assume that the change is significant.

The market growth is quite remarkable especially when one considers changes in the life insurance sector, where the number of companies has increased sixfold over the course of the analysed period. The rapid growth in the life insurance world sector has probably contributed to these changes. According to the world's data, the life insurance industry has grown rapidly at approximately 30 per cent annually, while the non-life sector has grown at approximately 19 per cent. ${ }^{1}$ The life insurance sector has undergone fast development in Poland as well. Suffice to say, during the transition period, the gross written premium increased approximately 60-fold, whereas non-life insurance, in the same period of time, increased only ten times. ${ }^{2}$ Therefore, it is interesting to answer the question: What factors have determined life insurance development in Poland and to what extent? The research presented herein illustrates our attempt to answer this question.

It is also important to know that the development of the Polish life insurance market can be divided into four main stages, which result from historical events.

The first stage was the period of occupation by Russia, Prussia and Austria, ending in 1918. The second stage is a development stage, starting in 1918 and ending with the outbreak of World War II. It is followed by the third stage, which comprises the Communist era, when the insurance sector can be characterised as a centrally planned State monopoly. As mentioned, this period ended in 1990 when the new insurance act came into force.

In the Communist era, State-owned companies dominated the insurance market in Poland. In the life insurance sector, 98.43 per cent of gross written premiums came

\footnotetext{
${ }^{1}$ Browne and Kim (1993).

${ }^{2}$ Calculation based on data published by the Polish FSA. A gross premium written for life insurance in 1991 was equal to PLN $208 \mathrm{~m}$ and in 2004 the premium was equal to PLN 12,735 m (as a nominal value).
} 
from group insurance organised by big State-owned companies. The gross written premiums from individual policies accounted for merely 1.57 per cent. The first wave of change came in 1984 when the Communist government amended the existing insurance act. The act allowed private companies to operate. However, the share of private capital could not exceed 49 per cent of total subscribed capital, which in practice let the State exercise full control over this area of economy.

The situation changed radically after 1990, when the new insurance act was introduced. The new act distinguished the life insurance and non-life insurance markets and, for the first time, allowed foreign investors to invest in the Polish insurance industry with no limits imposed on the level of shareholding. The new competitive market replaced the State monopoly. In the life insurance sector, more than five companies began to operate at that time, international companies above all, such as AIG Life, Nationale Nederlnden Life and Commercial Union. Since 1991, the number of companies licensed to transact life insurance business has increased six times. Table 3 shows the number of insurance companies within the period from 1991 to 2008 (chosen year).

The insurance market has been undergoing significant structural changes for the last 18 years. The share of the life insurance gross written premiums in total premiums rose from 14 per cent in 1991 to 66 per cent in 2008. After 2005, when the share reached 50 per cent, the market could theoretically be considered to be mature (the end of transition period). Figure 2 shows changes in insurance market gross written premiums structure according to the type of insurance.

Accordingly, the increase in the number of insurance companies entailed a significant growth of the value of subscribed capital. At the end of 2008, the total value of the subscribed capital equalled $1,766,355 \mathrm{USD}^{3}$ and, in nominal terms, it was more than $c a$. sixfold higher than in 1997. The changes in the value of subscribed capital grew faster with regard to life insurance. The value of the capital during this period increased slightly more than eight times. The change of the nominal value of subscribed capital in 2008, compared to the figure in 1997, is shown in Table 4. The value of subscribed capital for earlier years cannot be compared due to the redenomination that took place in Poland in $1995 .^{4}$

Furthermore, in the analysed period, the share of foreign capital in subscribed capital grew rapidly and reached 78.58 per cent with regard to life insurance. Life insurance companies with foreign capital account for more than 77.06 per cent of the total life insurance gross written premiums. Figure 3 shows the changes in ownership structure during the transition.

The most dynamic period of growth in foreign investment was by the end of the 1990s. Probably due to the global economic decrease and national economic recession, the Polish life insurance market entered a period of growth stabilisation after ten years of dynamic and fast development, which lasted until 2002. Table 5 shows the changes

\footnotetext{
${ }^{3}$ USD $1=$ PLN 2.9618 average exchange rate at the end of 2008 according to the National Polish Bank (www.nbp.pl).

${ }^{4}$ As a result of inflation in the early 1990s, the currency underwent redenomination. Thus, on 1 January 1995, 10,000 old zlotych (PLZ) became one new zloty (PLN).
} 
Table 3 Number of insurers during the transition period in Poland

\begin{tabular}{|c|c|c|c|c|c|c|c|c|c|c|c|c|c|c|c|c|}
\hline \multirow[t]{2}{*}{ No. } & \multirow[t]{2}{*}{ Branch } & \multicolumn{15}{|c|}{ Year } \\
\hline & & 1991 & 1992 & 1994 & 1995 & 1996 & 1997 & 1998 & 1999 & 2001 & 2002 & 2003 & 2004 & 2005 & 2007 & 2008 \\
\hline 1. & Life & 5 & 6 & 10 & 13 & 15 & 21 & 24 & 31 & 35 & 36 & 37 & 36 & 32 & 32 & 30 \\
\hline 2. & Non-life & 19 & 20 & 26 & 27 & 31 & 32 & 31 & 36 & 33 & 35 & 36 & 37 & 35 & 35 & 36 \\
\hline 3. & Total & 24 & 26 & 36 & 40 & 46 & 53 & 55 & 67 & 68 & 71 & 73 & 74 & 67 & 67 & 66 \\
\hline
\end{tabular}

Source: Polish Insurance Chamber (www.piu.org.pl/raport-roczny-piu).

Share of gross written premium according to the insurance branches

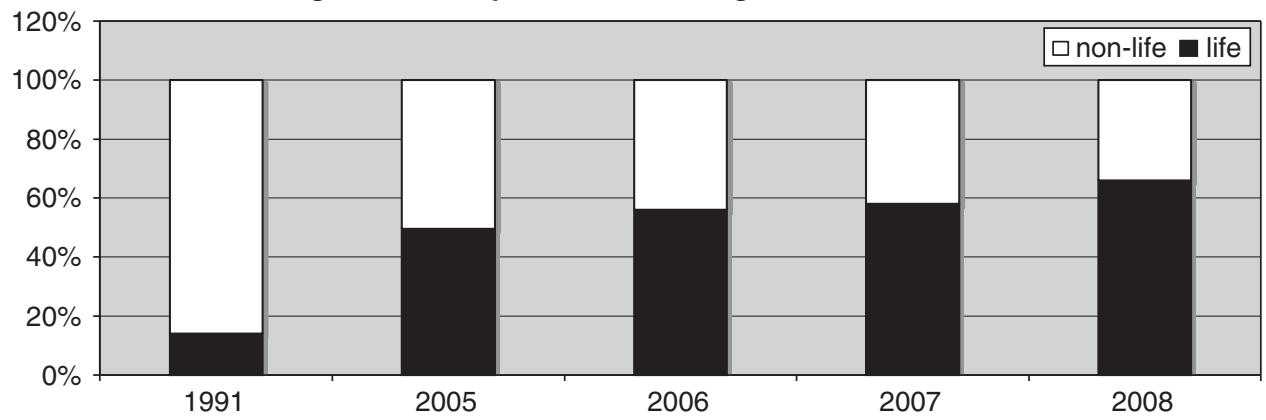

Figure 2. Gross premium written structure according to type of insurance in 1991, 2005, 2006, 2007 and 2008. Source: Based on data published by the Polish Insurance Chamber (www.piu.org.pl).

of a nominal value of foreign capital in the life insurance market. The figures are provided in U.S. dollars.

\section{Review of previous studies on life insurance demand}

Hammond et al. ${ }^{5}$ devised the first model of life insurance demand in their study focused on demographic and social factors, such as order of birth, age, level of education, number of dependants. They discussed the influence of these factors on the optimisation of life insurance consumption level. Subsequently, more and more researchers became involved in the study on life insurance demand determinants, which was strongly related to the dynamic growth of the world's life insurance sector. As mentioned above, in the world economy, during the period of development and reconstruction, after the end of World War II to the 1990s, the life insurance sector was growing by ca. 30 per cent annually. ${ }^{6}$ Successive studies have evolved making greater use of economic factors, such as life insurance price, inflation or disposable

\footnotetext{
${ }^{5}$ Hammond et al. (1967).

${ }^{6}$ Browne and Kim (1993).
} 
Table 4 The change in terms of subscribed capital of insurance companies (nominal value)

\begin{tabular}{|c|c|c|c|c|}
\hline \multirow[t]{2}{*}{ No. } & \multirow[t]{2}{*}{ Branch } & \multicolumn{2}{|c|}{ Year (thousands USD) ${ }^{\mathrm{a}}$} & \multirow[t]{2}{*}{ Change (\%) } \\
\hline & & 1997 & 2008 & \\
\hline 1. & Life & 105,290 & 845,579 & 703 \\
\hline 2. & Non-life & 191,641 & 920,776 & 380 \\
\hline 3. & Total & 296,931 & $1,766,355$ & 495 \\
\hline
\end{tabular}

${ }^{\text {a }}$ To convert to U.S. dollars, we used average exchange rates at the end of the particular year. The exchange rates are published by the Polish National Bank (www.nbp.pl/Kursy) in Table A. Thus, at the end of 1997 the dollar exchange rate amounted to PLN 3.518 for USD 1. At the end of 2008 the rate was PLN 2.9618 for USD 1.

Source: Authors' calculations.

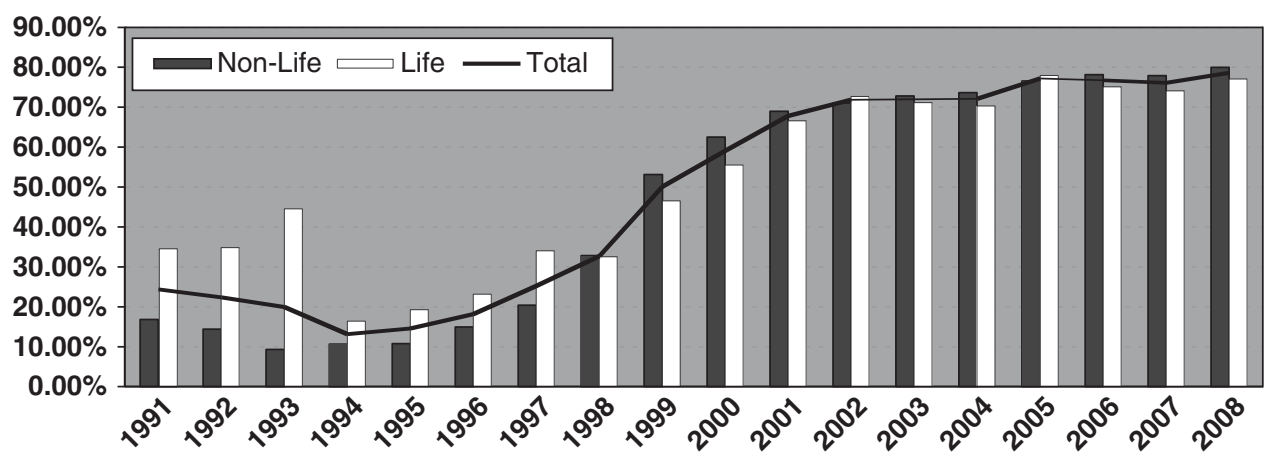

Figure 3. Changes in insurance industry ownership structures (share of foreign investments in subscribed capital). Source: Based on the data published by the Polish FSA.

income level. The chronological order of the best-known studies is presented in Table 6.

The authors used different techniques to assess the determination of life insurance demand. The majority of the studies were based on time-series data. For instance, the study by Manits and Farmer $^{7}$ applies simple correlation analysis to determine independent variables. The variables, such as relative price index, personal income, population, marriages, births and employment, were selected after their coefficient of correlation with dependent variable reached 0.85 . The authors resorted to manipulation when variables that they wanted to include in the analysis did not match the criteria. For instance, in the case of births and marriages, the prescribed way of choosing the features is rather simple. The methodology based on simple linear correlation could not eliminate the multi-collinearity problem, which can be proved by, for instance, Diacon ${ }^{8}$ who came to the conclusion that the autocorrelation and

\footnotetext{
${ }^{7}$ Mantis and Farmer (1968).

${ }^{8}$ Diacon (1980).
} 
Table 5 The changes (year-by-year) of foreign capital in the life insurance sector (nominal value)

\begin{tabular}{lrr}
\hline Year & Capital value $(U S D)^{\mathrm{a}}$ & Change $(\%)$ \\
\hline 1997 & $35,825,125$ & - \\
1998 & $64,641,199$ & 80 \\
1999 & $125,377,625$ & 94 \\
2000 & $208,343,647$ & 66 \\
2001 & $310,868,845$ & 49 \\
2002 & $391,821,403$ & 26 \\
2003 & $422,725,678$ & 8 \\
2004 & $508,119,489$ & 20 \\
2005 & $528,506,890$ & 4 \\
2006 & $682,530,250$ & 29 \\
2007 & $852,842,408$ & 25 \\
2008 & $651,645,190$ & -24 \\
\hline
\end{tabular}

${ }^{\text {a }}$ To convert to U.S. dollars, we used average exchange rates at the end of the particular year. The exchange rates are published by the Polish National Bank (www.nbp.pl/Kursy) in Table A. Thus, at the end of 1997 the dollar exchange rate amounted to PLN 3.518 for USD 1. At the end of 2008, the rate was PLN 2.9618 for USD 1.

Source: Authors' calculations.

multi-collinearity effect makes the demand determination results difficult to describe. Therefore, there is still a risk that the chosen features could influence the level of life insurance demand in the same manner (carrying the same information).

Subsequent studies used more adequate techniques to choose independent variables. However, the multi-collinearity problem was not eliminated. The studies looked into factors such as interest rates, price of insurance, social security, education level and tax contribution and their influence on the amount of life insurance expenditures.

Specific factors were investigated by Neumann ${ }^{9}$ and Headen and Lee. ${ }^{10}$ For instance, Rejda et al. ${ }^{11}$ also proved that social security and tax incentives influenced the growth of group life insurance premium. Gutter and Hatcher ${ }^{12}$ demonstrated that the demand for life insurance was also determined by racial differences.

The dependency ratio is also a substantial factor of life insurance demand. The influence of the ratio was investigated in a number of studies. The vital role of the ratio is confirmed by the research by Hammond et al. ${ }^{5}$ who found that one of the main purposes of life insurance was to protect dependants against financial problems in the case of a wage-earner's premature death. ${ }^{13}$ These findings are in harmony with the results of Lewis's research. Furthermore, a strong relationship between the number of dependants and life insurance demand was confirmed by the study by Beenstock et al. ${ }^{14}$

\footnotetext{
${ }^{9}$ Neumann (1969).

${ }^{10}$ Headen and Lee (1974).

11 Rejda et al. (1987).

12 Gutter and Hatcher (2008).

${ }^{13}$ Browne and Kim (1993, p. 621).

14 Beenstock et al. (1986).
} 
Table 6 Studies on life insurance demand in chronological order

\begin{tabular}{|c|c|c|c|}
\hline $\begin{array}{l}\text { Year of } \\
\text { publication }\end{array}$ & Author $/ s$ & Journal & Title \\
\hline 1967 & $\begin{array}{l}\text { Hammond, Houston } \\
\text { and Melander }\end{array}$ & $J R I$ & $\begin{array}{l}\text { Determinations of Household Life Insurance Premium } \\
\text { Expenditures: An Empirical Investigation }\end{array}$ \\
\hline 1968 & Mantis and Farmer & $J R I$ & Demand for Life Insurance \\
\hline 1969 & Neuman & $J R I$ & Inflation and Savings through the Life Insurance \\
\hline 1969 & Duker & $J R I$ & $\begin{array}{l}\text { Expenditures for Life Insurance Among Working-Wife } \\
\text { Families }\end{array}$ \\
\hline 1971 & Whitaker and Lee & $J R I$ & $\begin{array}{l}\text { Competition Among Life Insurance Products Lines: } \\
\text { Determinants of Demand }\end{array}$ \\
\hline 1972 & Berekson & $J R I$ & $\begin{array}{l}\text { Birth Order, Anxiety, Affiliation and the Purchase of Life } \\
\text { Insurance }\end{array}$ \\
\hline 1973 & Fortune & $J R I$ & $\begin{array}{l}\text { The Theory of Optimal Life Insurance: Development and } \\
\text { Test }\end{array}$ \\
\hline 1974 & Lee and Headen & $J R I$ & $\begin{array}{l}\text { Life Insurance Demand and Household Portfolio } \\
\text { Behaviour }\end{array}$ \\
\hline 1975 & Nevin and Anderson & $J R I$ & $\begin{array}{l}\text { Determinants of Young Marrieds' Life Insurance } \\
\text { Purchasing Behaviour: An Empirical Investigation }\end{array}$ \\
\hline 1980 & Diacon & GPRIIP & The Demand for U.K. Ordinary Life Insurance: 1946-1968 \\
\hline 1980 & Lee and Ferber & $J R I$ & $\begin{array}{l}\text { Acquisition and Accumulation of Life Insurance in Early } \\
\text { Married Life }\end{array}$ \\
\hline 1981 & Babbel & $J R I$ & Inflation, Indexation, and Life Insurance Sales in Brazil \\
\hline 1984 & Palmer and Burnett & $J R I$ & $\begin{array}{l}\text { Examining Life Insurance Ownership Through } \\
\text { Demographic and Psychographic Characteristics }\end{array}$ \\
\hline 1985 & Babbel & $J R I$ & $\begin{array}{l}\text { The Price Elasticity of Demand for Whole Life } \\
\text { Insurance }\end{array}$ \\
\hline 1985 & Miller & $M L R$ & Age Related Reductions in Worker's Life Insurance \\
\hline 1986 & Wiliams & $J R I$ & $\begin{array}{l}\text { Higher Interest Rates, Longer Lifetimes, and the Demand } \\
\text { for Life Annuities }\end{array}$ \\
\hline 1987 & Fitzgerald & $J R I$ & $\begin{array}{l}\text { The Effect of Social Security on Life Insurance Demand by } \\
\text { Married Couples }\end{array}$ \\
\hline 1989 & Lewis & $A E R$ & Dependents and the Demand for Life Insurance \\
\hline 1989 & $\begin{array}{l}\text { Kotlikoff and } \\
\text { Auerbach }\end{array}$ & $J R I$ & $\begin{array}{l}\text { The Demand for Life Insurance in Mexico and U.S.: } \\
\text { A Comparative Study }\end{array}$ \\
\hline 1991 & Bernheim & $J R I$ & $\begin{array}{l}\text { How Strong Are Bequest Motives? Evidence Based } \\
\text { on Estimates of the Demand for Life Insurance and } \\
\text { Annuities }\end{array}$ \\
\hline 1993 & Browne and Kim & $J R I$ & An International Analysis of Life Insurance Demand \\
\hline 1994 & Showers and Shotick & $J R I$ & $\begin{array}{l}\text { The Effects of Household Characteristics on Demand for } \\
\text { Insurance: A Tobit Analysis }\end{array}$ \\
\hline 1996 & Outreville & $J R I$ & Insurance Markets in Developing Countries \\
\hline 1996 & Miners and Gandolfi & $J R I$ & Gender Based Differences in Life Insurance Ownership \\
\hline 1998 & Guiso and Jappelli & $G P R I T$ & $\begin{array}{l}\text { Background Uncertainty and the Demand for Insurance } \\
\text { Against Insurable Risks }\end{array}$ \\
\hline 2000 & Hau & $J R I$ & $\begin{array}{l}\text { Liquidity, Estate Liquidation, Charitable Motives, and Life } \\
\text { Insurance Demand by Retired Singles }\end{array}$ \\
\hline 2001 & Lee, Chen and Wong & $J R I$ & $\begin{array}{l}\text { Age, Period, and Cohort Effects on Life Insurance in } \\
\text { the U.S. }\end{array}$ \\
\hline 2002 & $\begin{array}{l}\text { Ward and } \\
\text { Zurbruegg }\end{array}$ & GPRIIP & Law, Politics and Life Insurance Consumption in Asia \\
\hline 2003 & Hwang and Gao & $J M F$ & $\begin{array}{l}\text { The Determinants of the Demand for Life Insurance in an } \\
\text { Emerging Economy-The Case of China }\end{array}$ \\
\hline
\end{tabular}


Table 6 (continued)

\begin{tabular}{|c|c|c|c|}
\hline 2004 & Somerville & $A E R$ & $\begin{array}{l}\text { Insurance Consumption and Saving: A Dynamic Analysis } \\
\text { in Continuous Time }\end{array}$ \\
\hline 2005 & $\begin{array}{l}\text { Ward, Zurbruegg and } \\
\text { Hussles }\end{array}$ & $R M I R$ & Stimulating the Demand for Insurance \\
\hline 2007 & Lin and Grace & $J R I$ & $\begin{array}{l}\text { Household Life Cycle Protection: Life Insurance Holdings, } \\
\text { Financial Vulnerability, and Portfolio Implication }\end{array}$ \\
\hline 2007 & $\begin{array}{l}\mathrm{Li} \text {, Moshirian, } \\
\text { Nguyen and Wee }\end{array}$ & $J R I$ & The Demand for Life Insurance in OECD Countries \\
\hline 2008 & $\begin{array}{l}\text { Gutter and } \\
\text { Hatcher }\end{array}$ & $J R I$ & Racial Differences in the Demand for Life Insurance \\
\hline 2008 & Chui and Cy Kwok & $J I B S$ & National Culture and Life Insurance Consumption \\
\hline 2008 & Sen & $* *$ & $\begin{array}{l}\text { An Analysis of Life Insurance Demand Determinants for } \\
\text { Selected Asian Economies and India }\end{array}$ \\
\hline 2010 & Kakar and Shukla & $J A E R$ & $\begin{array}{l}\text { The Determinants of Demand for Life Insurance in an } \\
\text { Emerging Economy-India }\end{array}$ \\
\hline
\end{tabular}

** Working papers 36/2008 of Madres School of Economics.

JMF-Journal of Managerial Finance, AER-The American Economic Review, RMIR-Risk Management \& Insurance Review, JRI-Journal of Risk \&Insurance, JIBS-Journal of International Business Studies, MLR-Monthly Labour Review, AER-American Economic Review, JAER-The Journal of Applied Economics Research, GPRIT-The Geneva Papers on Risk and Insurance Theory, GPRIIP-The Geneva Papers on Risk and Insurance-Issues and Practice.

Source: Authors based on E.N. Zietz (2003, p. 168).

There are a great number of variables examined in the analysis of life insurance demand. However, our investigation has led to a study that applies factor analysis in order to distinguish the variables. The proposed approach minimises the problem of multi-collinearity. Multi-collinearity occurs because two (or more) variables are related - they measure essentially the same thing. If one of the variables does not seem logically essential to the model, its removal may reduce or even eliminate multi-collinearity. The study of literature on the subject shows that all chosen variables were significant determinants of demand for life insurance. Therefore, eliminating variables is not our intention, which justifies the application of the factor analysis. The approach that assumes grouping the variables into the factors minimises the problem of multi-collinearity. In the previous studies, authors overlooked the fact that different variables can carry the same information. For instance, Gross Domestic Product (GDP) and inflation or per cent rate could influence life insurance demand in the same manner. If it is true, it is better to cumulate those variables in one independent factor and then check the direction and power of the determination.

Most variables used in our study have been selected on the basis of the review of the literature on the subject. The demand for life insurance is expressed by the change in gross written premium in the sector. This approach was widely used in previous studies. For example, the most common variables that are taken into account include income, age, education and the level of GDP. Our study also deals with these variables. Table 7 shows the most frequently used variables, the number of studies in 
Table 7 Selected variables and their impact on the demand for life insurance

\begin{tabular}{|c|c|c|c|c|}
\hline \multirow[t]{2}{*}{$\#$} & \multirow[t]{2}{*}{ Variables } & \multicolumn{2}{|c|}{ Sign of determination } & \multirow[t]{2}{*}{ Non-significant feature } \\
\hline & & Positive & Negative & \\
\hline \multicolumn{5}{|c|}{ Financial and economic variables } \\
\hline 1. & Income & 13 & 1 & 1 \\
\hline 2. & Household income & 1 & & \\
\hline 3. & Net assets & 9 & 1 & 2 \\
\hline 4. & Insurance price & & 2 & \\
\hline 5. & Inflation and percent rate & 2 & 1 & 1 \\
\hline 6. & Expected prices & 1 & 1 & \\
\hline 7. & Social security & 2 & 3 & 1 \\
\hline \multicolumn{5}{|c|}{ Personal and demographic variables } \\
\hline 1. & Age & 3 & 4 & 6 \\
\hline 8. & Level of education & 6 & 3 & \\
\hline 11. & Dependency ratio & 6 & 2 & 1 \\
\hline 12. & Sex & 1 & & \\
\hline 13. & Marital status & & 2 & 2 \\
\hline 16. & Population & 1 & & \\
\hline 17. & Expected prices & & 1 & \\
\hline
\end{tabular}

Source: Authors based on Zietz (2003).

which these variables were taken into consideration and the sign of determination of life insurance demand.

In addition, variables such as the development of the financial market, market structure (number of companies), the share of foreign investors and life expectancy for women and men have been included. These variables were the focus of the study conducted by Outreville. ${ }^{15}$ Outreville checked the variety of variables and their relation to life insurance demand. In his study, independent variables were represented by GDP, real interest rate, anticipated inflation, life expectancy, the level of financial development, rural population, level of education, health status, Muslim population, social security, dependency ratio, HDI (Human Development Index) and population growth rate. He focused on 48 developing countries and provided a cross-section analysis. Outreville applied the least square method to estimate the impact coefficients. He used the Park test to verify the assumption of homoscedasticity by regressing the difference between the results obtained through observation and those acquired through theoretical calculation obtained from the regression on the size variable. On the basis of the analysis of correlation, he reduced the number of preliminary variables and created the reduced-form equation. The results of Outreville's reduced-form equation are presented in Table 8 . His results confirmed that most of the listed variables are of significant importance in the determination of demand for life insurance.

\footnotetext{
${ }^{15}$ Outreville (1996).
} 
Table 8 The results obtained by J.F. Outreville

\begin{tabular}{|c|c|c|c|c|c|}
\hline \multirow[t]{2}{*}{ \# } & \multirow[t]{2}{*}{ Variables } & \multicolumn{2}{|c|}{ Linear model } & \multicolumn{2}{|c|}{ Logarithmic model } \\
\hline & & Parameter & t-distribution & Parameter & t-distribution \\
\hline 1. & GDP per capita & 0.0002 & 2.76 & 0.52 & 2.75 \\
\hline 2. & Real Interest Rate & 0.0025 & 0.77 & -0.0027 & 0.81 \\
\hline 3. & Anticipated Inflation & -0.84 & 1.92 & -0.93 & 2.14 \\
\hline 4. & Life expectancy & 0.11 & 4.81 & 0.09 & 3.32 \\
\hline 5. & Level of financial development & 0.01 & 1.48 & 0.02 & 1.73 \\
\hline 6. & Monopolistic market & -2.51 & 6.06 & -2.28 & 5.44 \\
\hline 7. & Foreign companies in the market & -0.16 & 0.45 & -0.13 & 0.36 \\
\hline 8. & Intercept & \multicolumn{2}{|c|}{-3.63} & \multicolumn{2}{|c|}{-5.27} \\
\hline 9. & $R^{2}$ & \multicolumn{2}{|c|}{0.85} & \multicolumn{2}{|c|}{0.85} \\
\hline
\end{tabular}

Source: Outreville (1996, p. 270).

Outreville used the appropriate relationship of monetary aggregates M1 and M2 as a variable representing the country's financial development. This indicator was calculated as the difference between the aggregate money M1 and M2 in relation to aggregate M2. Taking into account the definition of monetary aggregates M1 and M2, the indicator could be understood as fixed-term deposits in total money supply aggregate M2. This could be interpreted as the level of savings.

The most recent studies on the determinants of aggregate life insurance demand on a cross-section on developed economics were conducted by Li et al., ${ }^{16}$ who analysed the demand determinants on the example of OECD countries. The primary conclusion confirms that income plays a key role in the process of determining life insurance demand. According to the authors, a 1 per cent increase in aggregate income could induce $c a$. 0.6 per cent increase in aggregate life insurance demand. The results of the study are also consistent with the dependants' expected lifetime utility theory proposed by Lewis. ${ }^{17}$ In particular, the demand decreases in line with average life expectancy and increases with the changes of dependency ratio. All the socio-economic factors considered by the authors, such as education level, dependency ratio and social security expenditure, play an important role in the demand for life insurance.

Kakar and Shukla ${ }^{18}$ conducted a research on life insurance demand using the example of India as an emerging market. Their results also confirm previous conclusions, proving that socio-economic factors, such as income and education level, significantly influence demand.

\section{Identification of the determinants of life insurance demand}

On the basis of the analyses of the type of variables previously used by the authors listed in Table 5, we enumerated the following set of 15 variables. As explained earlier

\footnotetext{
${ }^{16}$ Li et al. (2007).

${ }^{17}$ Lewis (1989).

${ }^{18}$ Kakar and Shukla (2010).
} 
Table 9 Variables chosen for an investigation

\begin{tabular}{ll}
\hline Symbol & Chosen variables \\
\hline$X_{1}$ & Gross domestic product \\
$X_{2}$ & Percent rate \\
$X_{3}$ & Inflation \\
$X_{4}$ & Financial development \\
$X_{5}$ & Men's life expectancy \\
$X_{6}$ & Women's life expectancy \\
$X_{7}$ & Monopolistic market (number of competitors) \\
$X_{8}$ & Share of foreign companies in a market (share of foreign capital) \\
$X_{9}$ & Population \\
$X_{10}$ & Education level \\
$X_{11}$ & Health expenditures \\
$X_{12}$ & Social benefit \\
$X_{13}$ & Dependency ratio \\
$X_{14}$ & Rate of birth \\
$X_{15}$ & Unemployment rate \\
$Y$ & Gross written premiums (represents life insurance demand) \\
\hline
\end{tabular}

in this paper, the authors tried to include variables that occur in most of the previously discussed studies. The insurance demand was represented by gross written premiums (hereafter dependent variable). The variables chosen for the analysis are shown in Table 9.

The data used for the analysis comes from the databases of the Statistical Office of Poland for the period 1991-2005. In the case of the variable named "Financial development", the monetary aggregates M1 and M2 published by the Polish National Bank were used. The level of education represents the number of university graduates (postgraduate and undergraduate levels). The variable "Percent rate" represents the average rate $(A E R)$ of 12 months' deposits in the Polish banking system. "Monopolistic market" represents the change in the number of life insurance companies (see Table 3). The "Share of foreign companies in the market" was calculated as a change in the share of foreign investments during the transition period. The changes are provided in Table 5. However, in order to estimate the changes used in the study, the nominal value of the investment, expressed in Polish currency, was used. Variables used in the study, such as birth rate and average life expectancy, describe the age of the population living in the country. The birth rate stands for the average annual number of births during a year per 1,000 persons in the population at mid-year, which is also referred to as crude birth rate. The birth rate is usually the main factor in determining the rate of population growth. It is influenced by both the level of fertility and the age structure of the population.

The study estimated the change of values of all variables counted from year to year (index). For example, in terms of GDP, the values provided in Table 10 were used to calculate the changes.

Table 11 includes the descriptive statistic for all variables. The parameters were provided to show the significance of the changes during the transition period. For example, "Mean of GDP" of 121.41 per cent signifies that, on average, GDP grew by 
Table 10 The values of GDP and the change during the analysed period

\begin{tabular}{lccc}
\hline Year & GDP $($ in million $P L N)$ & Index $(\%)$ & Change $(\%)$ \\
\hline 1990 & $60,672.57$ & - & 35.87 \\
1991 & $82,432.99$ & 135.87 & 39.44 \\
1992 & $114,944.20$ & 139.44 & 35.53 \\
1993 & $155,780.00$ & 135.53 & 35.07 \\
1994 & $210,407.30$ & 135.07 & 60.27 \\
1995 & $337,221.90$ & 160.27 & 25.27 \\
1996 & $422,435.80$ & 125.27 & 22.00 \\
1997 & $515,353.80$ & 122.00 & 16.60 \\
1998 & $600,901.90$ & 116.60 & 10.88 \\
1999 & $666,308.30$ & 110.88 & 11.75 \\
2000 & $744,621.80$ & 111.75 & 4.64 \\
2001 & $779,204.70$ & 104.64 & 3.68 \\
2002 & $807,859.50$ & 103.68 & 4.24 \\
2003 & $842,120.40$ & 104.24 & 9.50 \\
2004 & $922,157.20$ & 109.50 & 6.37 \\
2005 & $980,883.70$ & 106.37 & \\
\hline
\end{tabular}

Source: Central Statistical Office of Poland.

Table 11 Descriptive statistics

\begin{tabular}{|c|c|c|c|c|c|c|}
\hline No. & Variables & $\begin{array}{c}\text { Mean } \\
(\%)\end{array}$ & $\begin{array}{c}\text { Standard } \\
\text { deviation }(\%)\end{array}$ & $\begin{array}{c}\text { Minimum } \\
(\%)\end{array}$ & $\begin{array}{c}\text { Maximum } \\
(\%)\end{array}$ & $\begin{array}{l}\text { Volatility } \\
\text { ratio (\%) }\end{array}$ \\
\hline 1. & Gross domestic product & 121.41 & 16.76 & 103.68 & 160.27 & 56.59 \\
\hline 2. & Percent rate & 19.08 & 14.84 & 3.17 & 50.30 & 47.13 \\
\hline 3. & Inflation & 119.09 & 19.53 & 100.80 & 170.30 & 69.50 \\
\hline 4. & Financial development & -57.44 & 9.12 & -81.03 & -51.54 & 29.49 \\
\hline 5. & Life expectancy (men) & 100.42 & 0.47 & 99.40 & 101.32 & 1.92 \\
\hline 6. & Life expectancy (women) & 101.23 & 3.19 & 98.53 & 112.39 & 13.86 \\
\hline 7. & Monopolistic market & 116.72 & 22.93 & 91.43 & 180.00 & 80.57 \\
\hline 8. & Share of foreign companies & 46.68 & 20.97 & 16.40 & 77.93 & 61.54 \\
\hline 9. & Population & 99.97 & 0.30 & 98.97 & 100.28 & 1.32 \\
\hline 10 . & Education level & 0.45 & 0.34 & 0.00 & 1.00 & 1.00 \\
\hline 11. & Health expenditures & 9.31 & 6.20 & 1.94 & 16.06 & 14.13 \\
\hline 12. & Social benefits & 6.62 & 2.84 & 0.10 & 9.34 & 9.24 \\
\hline 13. & Dependency ratio & 51.42 & 4.40 & 44.85 & 57.66 & 12.81 \\
\hline 14. & Rate of birth & 0.10 & 0.13 & -0.04 & 0.37 & 0.41 \\
\hline 15. & Unemployment rate & 15.21 & 2.98 & 10.30 & 20.00 & 9.70 \\
\hline
\end{tabular}

Source: Authors' calculations.

21.41 per cent in this period. The minimum change in GDP was 3.68 per cent and the maximum was 60.27 per cent. The interpretation of parameters of other variables is similar.

Gross domestic product, inflation, share of foreign capital and monopolistic market were very volatile within the analysed period. As mentioned before, a monopolistic market is represented by a change in the number of companies. The volatility ratio for 
the variable reached the highest level of almost 81 per cent, which explains why the number of companies changed so significantly within the transition period.

The implementation of the factor analysis led to the reduction of the set of chosen variables (preliminary). The reduction of the set of variables achieved by applying and constructing aggregate factors is the main advantage of this study. The use of the factor analysis and the reduction of preliminary variables made it possible for us to minimise the problem of multi-collinearity. It is also noteworthy that the obtained factors have a relatively easy and distinct economic interpretation. Prior to factor analysis, the correlation coefficients between all chosen variables were calculated. The coefficients are presented in a table attached to the paper as Appendix. Higher values of the coefficients justify the application of factor analysis. The stronger the correlation between particular variables, the better the justification for application of the proposed methodology. The results show that there is a strong relation between the variables. There is also a strong correlation among particular variables and the dependent variable. The exceptions include variables $X_{6}$ (women's life expectancy), $X_{12}$ (social benefit) and $X_{9}$ (population). Social benefits are relatively low in Poland. Table 11 shows that social benefits accounted for 6.62 per cent on average of total GDP in the discussed period. The lack of correlation in terms of population results from the fact that the level of population changed only slightly during the transition period. From the analysis of the data provided in Table 11, it can be concluded that the change was hardly visible. Nevertheless, we decided to keep the variables for further analyses. The variables $X_{5}$ and $X_{6}$ are usually highly correlated. However, the result of our study on Poland during the transition does not confirm this, which is probably due to the specific aspect of the country, where women's life expectancy has been increasing faster than men's. This provided a good reason for including those two variables separately.

The next step of the study was the application of the Bartlett test of sphericity. The test was used to confirm the severity of the results since the observations had been made on a random sample.

The Bartlett test verifies the significance of correlation coefficients between variables. For example, Outreville ${ }^{19}$ found no statistically significant relationship between variables in his study. However, for the purpose of our study, the relation between variables is vital, which is why we applied factor analysis to reduce (by merging) the number of preliminary variables into a set of factors. The adequacy of the sample was verified by Kaiser-Mayer-Olkin $(\mathrm{K}-\mathrm{M}-\mathrm{O})$ statistics. ${ }^{20}$ The $\mathrm{K}-\mathrm{M}-\mathrm{O}$ is a measure of the suitability of the sample for the assumption of factor analysis. The level of sample adequacy for factor analysis measured by $\mathrm{K}-\mathrm{M}-\mathrm{O}$ statistics exceeds 0.9 . Such a level is regarded as very high. Table 12 contains communalities estimated for the realisation of a chosen set of variables.

High values of all communalities indicate that the random factors' influence on the factor analysis model is slight.

\footnotetext{
${ }^{19}$ Outreville (1996, p. 226).

${ }^{20}$ Kaiser (1974).
} 
Table 12 Communalities estimated

$X_{1}-\mathrm{GDP}$

$X_{2}$ - percent rate

$X_{3}$-inflation

0.972

$X_{4}$-financial development

0.798

$X_{5}$ - life expectancy (men)

0.640

$X_{6}$ - life expectancy (women)

0.734

$X_{7}$-monopolistic market

0.578

$X_{8}$ - share of foreign capital

$X_{9}$ - urbanisation ratio

0.749

$X_{10}$ education level

0.878

$X_{11}$ - share of health expenditures in GDP

0.914

$X_{12}$-social benefits

0.942

$X_{13}$ - dependency ratio

0.971

$X_{14}$-rate of birth

0.954

$X_{15}$-unemployment rate

0.644

Source: Authors' calculations.

The factor loadings are extracted by the principal axis factoring procedure. The number of extracted factors is determined by a sum of their variation coefficients or a number of eigenvalue (from reduced matrix) higher than one according to the Kaiser criterion. Estimated eigenvalues and their share in volatility of the whole set of variables are presented in Table 13.

The first four factors have an eigenvalue higher than one denoted in bold in Table 13. Those factors also render 83.022 per cent variation for the whole set. Therefore, all preliminary variables can be extracted in four main factors. The matrix of factor loadings is presented in Table 14.

The Varimax rotation is applied to check the alternative solutions. Factor rotation is an important tool in interpreting factors. Varimax is one of the most popular orthogonal factor rotation methods. The reference axes of the factors are turned about the origin until some other position has been reached. First, non-rotated factor solutions extract factors in order of importance. Each accounts for a successively smaller portion of variance. The ultimate effect of rotating the factor matrix is to redistribute the variance from earlier factors to later ones to achieve a simpler, theoretically more meaningful factor pattern. ${ }^{21}$ The obtained results are shown in Table 15.

To identify factors, it is necessary to group the variables that have large loadings for the same factors. In Table 15, the biggest values of factors' loadings are marked in bold. The higher levels of factor loadings were the criterion for assignment of variables to a particular factor. As a result, the first factor can represent the level of economic development since it integrates such variables as GDP, interest rate, inflation index, financial development, dependency ratio and birth rate. The second factor covers the potential for future social development because it integrates such variables as monopolistic market, share of foreign companies, urbanisation ratio, share of health

\footnotetext{
${ }^{21}$ Hair et al. (1984).
} 
Table 13 Estimated eigenvalues

\begin{tabular}{lccc}
\hline Variable no. & Eigenvalue & $\begin{array}{c}\text { Share in total volatility } \\
\text { of set of variables }\end{array}$ & $\begin{array}{c}\text { Cumulative share in total } \\
\text { volatility of set of variables }\end{array}$ \\
\hline $\mathbf{1}$ & $\mathbf{8 . 1 0 9}$ & $\mathbf{5 4 . 0 5 7}$ & $\mathbf{5 4 . 0 5 7}$ \\
$\mathbf{3}$ & $\mathbf{1 . 8 4 1}$ & $\mathbf{1 2 . 2 7 5}$ & $\mathbf{6 6 . 3 3 3}$ \\
$\mathbf{4}$ & $\mathbf{1 . 3 5 4}$ & $\mathbf{9 . 0 2 8}$ & $\mathbf{7 5 . 3 6 0}$ \\
5 & $\mathbf{1 . 1 4 9}$ & $\mathbf{7 . 6 6 2}$ & $\mathbf{8 3 . 0 2 2}$ \\
6 & 0.844 & 5.627 & 88.650 \\
7 & 0.695 & 4.631 & 93.280 \\
8 & 0.441 & 2.940 & 96.221 \\
9 & 0.293 & 1.955 & 98.176 \\
10 & 0.121 & 0.806 & 98.982 \\
11 & 0.093 & 0.617 & 99.599 \\
12 & 0.044 & 0.290 & 99.889 \\
13 & 0.013 & 0.086 & 99.976 \\
14 & 0.003 & 0.017 & 99.993 \\
15 & 0.001 & 0.007 & 100.000 \\
\hline
\end{tabular}

Source: Authors' calculations.

Table 14 Factor loadings - first estimation

\begin{tabular}{|c|c|c|c|c|}
\hline Variables & Factor 1 & Factor 2 & Factor 3 & Factor 4 \\
\hline$X_{1}$ & 0.849 & 0.024 & 0.081 & -0.081 \\
\hline$X_{2}$ & 0.945 & -0.176 & 0.183 & 0.153 \\
\hline$X_{3}$ & 0.911 & -0.305 & 0.192 & 0.104 \\
\hline$X_{4}$ & -0.586 & 0.521 & -0.332 & -0.267 \\
\hline$X_{5}$ & -0.054 & 0.549 & -0.189 & 0.548 \\
\hline$X_{6}$ & -0.265 & 0.276 & 0.015 & 0.766 \\
\hline$X_{7}$ & 0.443 & 0.603 & -0.038 & -0.129 \\
\hline$X_{8}$ & -0.934 & -0.283 & 0.061 & 0.082 \\
\hline$X_{9}$ & 0.700 & 0.489 & 0.135 & -0.036 \\
\hline$X_{10}$ & -0.774 & 0.223 & 0.472 & -0.079 \\
\hline$X_{11}$ & 0.917 & 0.090 & -0.237 & -0.091 \\
\hline$X_{12}$ & -0.102 & 0.407 & 0.866 & -0.128 \\
\hline$X_{13}$ & 0.979 & 0.081 & 0.070 & 0.037 \\
\hline$X_{14}$ & 0.921 & -0.220 & 0.131 & 0.202 \\
\hline$X_{15}$ & -0.656 & -0.326 & 0.238 & 0.227 \\
\hline
\end{tabular}

Source: Authors' calculations.

expenditure in GDP and unemployment rate. The third factor can represent social barriers because it integrates such variables as education level and social benefits, while the fourth factor can describe demographic development since it integrates such variables as life expectancy for men and for women, respectively. The breakdown of the variables strongly connected with corresponding factors is presented in Table 16.

Factors are inferred from the observed variables and can be estimated as their linear combinations. The Anderson-Rubin method was used because it produces 
Table 15 Factor loadings after Varimax rotation

\begin{tabular}{|c|c|c|c|c|}
\hline Variables & Factor 1 & Factor 2 & Factor 3 & Factor 4 \\
\hline$X_{1}$ & 0.611 & 0.576 & -0.055 & -0.161 \\
\hline$X_{2}$ & 0.893 & 0.418 & -0.071 & -0.064 \\
\hline$X_{3}$ & 0.913 & 0.320 & -0.096 & -0.162 \\
\hline$X_{4}$ & $-\mathbf{0 . 8 8 2}$ & 0.109 & 0.002 & 0.092 \\
\hline$X_{5}$ & -0.161 & 0.217 & -0.034 & 0.752 \\
\hline$X_{6}$ & -0.040 & -0.202 & 0.073 & 0.828 \\
\hline$X_{7}$ & -0.011 & 0.744 & 0.109 & 0.111 \\
\hline$X_{8}$ & -0.505 & $-\mathbf{0 . 8 3 3}$ & 0.111 & 0.043 \\
\hline$X_{9}$ & 0.323 & 0.777 & 0.175 & 0.098 \\
\hline$X_{10}$ & -0.534 & -0.405 & 0.651 & 0.075 \\
\hline$X_{11}$ & 0.516 & 0.722 & -0.335 & -0.121 \\
\hline$X_{12}$ & -0.005 & 0.105 & 0.965 & 0.005 \\
\hline$X_{13}$ & 0.719 & 0.668 & -0.080 & -0.045 \\
\hline$X_{14}$ & 0.895 & 0.367 & -0.134 & -0.033 \\
\hline$X_{15}$ & -0.167 & -0.753 & 0.195 & 0.107 \\
\hline
\end{tabular}

Source: Authors' calculations.

uncorrelated scores with a standard deviation of $1 .{ }^{22}$ For each factor, the factor scores are obtained by multiplying the standardised values by the corresponding factor score coefficients.

$$
\begin{aligned}
F_{1}= & 0.066 X_{1}-0.224 X_{2}+0.241 X_{3}-0.352 X_{4}-0.019 X_{5} \\
& +0.151 X_{6}-0.16 X_{7}+0.027 X_{8}-0.035 X_{9}-0.028 X_{10} \\
& -0.029 X_{11}+0.073 X_{12}+0.098 X_{13}+0.235 X_{14}+0.154 X_{15}, \\
F_{2}= & 0.087 X_{1}-0.05 X_{2}+0.09 X_{3}+0.255 X_{4}+0.088 X_{5} \\
& -0.11 X_{6}+0.2977-0.208 X_{8}+0.23 X_{9}-0.018 X_{10} \\
& +0.159 X_{11}+0.068 X_{12}+0.091 X_{13}-0.074 X_{14}-0.259 X_{15}, \\
F_{3}= & 0.049 X_{1}+0.057_{2}+0.45 X_{3}-0.091 X_{4}-0.075 X_{5} \\
& -0.003 X_{6}+0.89 X_{7}+0.001 X_{8}+0.171 X_{9}+0.385 X_{10} \\
& -0.155 X_{11}+0.676 X_{12}+0.038 X_{13}+0.01 X_{14}+0.094 X_{15}, \\
& -0.073 X_{1}+0.05 X_{2}-0.019 X_{3}-0.049 X_{4}+0.567 X_{5} \\
F_{4}= & 0.658 X_{6}-0.044 X_{7}+0.003 X_{8}-0.073 X_{9}-0.026 X_{10} \\
& -0.045 X_{11}-0.053 X_{12}+0.03 X_{13}+0.081 X_{14}+0.089 X_{15} .
\end{aligned}
$$

\footnotetext{
22 Tucker (1971) and Harman (1967).
} 
Table 16 Variables assigned to particular factors

\begin{tabular}{ll}
\hline Factors & Variables \\
\hline I & Gross Domestic Product (GDP) \\
& Percent rate \\
& Inflation \\
& Financial development \\
& Dependency ratio \\
& Rate of birth \\
II & Monopolistic market \\
& Share of foreign companies \\
& Urbanisation ratio \\
& Share of health expenditures in GDP \\
& Unemployment rate \\
III & Education level \\
& Social benefits \\
IV & Life expectancy (Men) \\
& Life expectancy (Women) \\
\hline
\end{tabular}

Source: Authors based on the results shown in Table 15.

\section{Empirical model-Regression analysis}

To model the influence of factors on life insurance demand, a linear stepwise regression analysis is applied. In spite of this, correlation coefficients are calculated prior to the regression estimations. A short look at the coefficients presented in Table 17 could bring us to the conclusion that the first factor stimulates demand for life insurance. It also clearly shows that the power of stimulation depends on the period of delay between realisation of the factor (included features) and the dependent variable (life insurance demand). The longer the delay period, the bigger the power of stimulation. Therefore, economic development (factor $\mathrm{I}-F_{1}$ ) has a delay effect on life insurance demand.

However, likewise, the opposite effect on life insurance demand has a second factor. The factor becomes a significant non-stimulator for the demand after a third year of delay.

The third factor could be regarded as non-significant in determining life insurance demand. The determination is non-significant even if the delay is applied. The same situation applies in terms of factor four, which could be perceived as a nonsignificant stimulant when current time is applied. However, if the delay is considered the factor influence changes and non-significantly adversely affects the demand (Table 17).

The regression analysis was done as a complement to the research, essentially to demonstrate that the extracted factors fit into the model (Table 18). $P$-value has a low level and therefore it can be concluded that the model is good. However, the main purpose of this paper is to demonstrate the possibility of the secretion of specific factors determining the demand for life insurance. As mentioned in the existing 
Table 17 Correlation coefficient between demand for life insurance (dependent variable) in period $t+k$ and independent factors in period $t$

\begin{tabular}{|c|c|c|c|c|}
\hline \multirow[t]{2}{*}{ Dependent variable lag $(k)$} & \multicolumn{4}{|c|}{ Factors } \\
\hline & $F_{1(t)}$ & $F_{2(t)}$ & $F_{3(t)}$ & $F_{4(t)}$ \\
\hline 0 & 0.458 & 0.269 & -0.156 & 0.238 \\
\hline 1 & 0.828 & 0.118 & -0.339 & -0.364 \\
\hline 2 & 0.783 & 0.253 & -0.344 & -0.366 \\
\hline 3 & 0.771 & 0.033 & -0.324 & -0.157 \\
\hline 4 & 0.920 & -0.376 & -0.033 & -0.064 \\
\hline 5 & 0.952 & -0.724 & 0.011 & -0.022 \\
\hline 6 & 0.902 & -0.811 & 0.241 & -0.196 \\
\hline
\end{tabular}

Source: Authors' calculations, $t$-period of observation.

Table 18 Estimated regression equations of independent factors on the life insurance demand in the period $t+k$

\begin{tabular}{|c|c|c|c|c|}
\hline $\begin{array}{l}\text { Demand for life insurance } \\
\text { in period: (lag) }\end{array}$ & Estimated equation & $R^{2}$ & Adjusted- $R^{2}$ & P-value \\
\hline 0 & Non-significant solution & - & - & - \\
\hline 1 & $Y=1.384+0.316 F_{1}-0.135 F 4$ & 0.902 & 0.780 & $<0.001$ \\
\hline \multirow[t]{2}{*}{2} & $Y=1.272+0.145 F_{1}+0.082 F 2$ & 0.879 & 0.773 & 0.001 \\
\hline & $Y^{*}=1.278+0.141 F_{1}+0.073 F_{2}-0.45 F_{4}$ & 0.916 & 0.839 & 0.001 \\
\hline 3 & $Y=1.26+0.111 F_{1}$ & 0.771 & 0.595 & 0.003 \\
\hline 4 & $Y=1.233+0.127 F_{1}$ & 0.920 & 0.846 & $<0.001$ \\
\hline 5 & $Y=1.214+0.121 F_{1}$ & 0.952 & 0.906 & $<0.001$ \\
\hline 6 & $Y=1.183+0.092 F_{1}$ & 0.902 & 0.813 & 0.001 \\
\hline
\end{tabular}

*Significance level of the $F_{4}$ factor is equal to 0.086 .

Source: Authors' estimations.

studies, the proposed approach was not applied. The authors used a regression model to verify the determination of the demand for life insurance. The authors of the previous study did not use any method to extract the factors made up with the preliminary variables. An exception may be mentioned here: the study conducted by Mantis and Farmer, ${ }^{23}$ where prior to the adoption of a particular feature the correlation with the test problem was checked. The feature was used for further testing if the correlation coefficient was more than 0.85 . The aim of this study is to present a different approach consisting in the first phase of the creation of independent factors. Selected variables make up the factors. Thus, as was mentioned earlier in the text, the problem of multi-collinearity is limited.

The regression model was created using the previously extracted factors. The model is not built by using the preliminary variables, which, undoubtedly, is another advantage of our study.

\footnotetext{
${ }^{23}$ Mantis and Farmer (1968).
} 


\section{Conclusions}

The study facilitates a visible comparison between the demand for life insurance in emerging markets with the demand in more traditional industrialised markets. This work examines life insurance demand in Poland. The Polish life insurance market constitutes a small portion of global life insurance premium, but is still the largest life insurance market in the CEE countries. The main aim of the research is to create a set of relatively independent life insurance demand factors by merging preliminary variables (GDP, percent rate, inflation, financial development, men and women's life expectancy, market monopolisation, share of foreign capital, population, level of education, expenditures on health and social care, dependency ratio). The methodology brought us to create four main factors.

As has already been stated, the advantage of the study is the use of relatively independent factors that were created by merging preliminary variables. While analysing previously published articles on this topic, we did not find a similar approach. Therefore, it is difficult to make direct comparisons with other countries or regions in terms of the demand determination.

Taking into account the behaviour of the extracted factors, however, it could be confirmed that the factor of an economic and financial nature (factor 1) is the most important one. The first factor is obtained by merging variables such as GDP, percent rate, inflation, financial development, dependency ratio and birth rate. The factor significantly stimulates the demand for life insurance. The longer the delay period is, the stronger the determination. In this case, it is very similar to western countries, where the economic and financial features strongly stimulate the demand for life insurance.

The second factor is a similar case. While the first factor stimulates the demand for life insurance, the second affects it adversely. This factor is obtained by merging the following variables: monopolistic market, share of foreign companies, urbanisation ratio, share of health expenditure in GDP and unemployment rate. It is also quite interesting that the second factor, which could be regarded as a potential future social development, has a delayed negative impact on life insurance demand. The previous studies show that the variables included in the second factor affect the demand for life insurance.

Somewhat surprising is the result for the third factor. The third factor comprises variables such as education level and social benefits. The factor has a rather nonsignificant influence on the demand for life insurance. In most studies, the level of education strongly determines (stimulates) the demand for life insurance, especially in industrialised markets. Such a strong stimulation could not be determined definitely in the case of Poland. This may be caused by a still low level of social insurance messages (consciousness).

The fourth one (men and women's life expectancy) has a positive but rather nonsignificant impact on the demand. However, the impact changes to negative after one year's delay. This confirms the results of Outreville's study of other developing countries. The average life expectancy could be interpreted as the actuarial price of certain types of life insurance. The result contradicts the Mantis and Farmer survey conducted using the United States as the example. The survey has shown a positive relationship between demand and price. 
The paper enriches the literature on the factors that have an impact on the demand for life insurance. Nowadays, the demand for life insurance in Poland seems to be determined more like in western European countries. However, the transition period was needed to change the behaviour (attitude) of Polish customers, which could be seen by applying lags to our study. The comparison of life insurance demand determinants in Poland with the situation in other CEE countries would be a good direction for further research in the field.

\section{References}

Babbel, D.F. (1981) 'Inflation, indexation, and life insurance sale in Brazil', The Journal of Risk and Insurance 48(1): 111-135.

Babbel, D.F. (1985) 'The price elasticity of demand for whole life insurance', The Journal of Finance 40(1): 225-239.

Berekson, L.L. (1972) 'Birth order, anxiety, affiliation and the purchase of life insurance', Journal of Risk and Insurance 39(1): 93-108.

Bernheim, B.D. (1991) 'How strong are bequest motives? Evidence based on estimates of the demand for life insurance and annuities', Journal of Political Economy 99(5): 899-927.

Beenstock, M., Dickinson, G. and Khajuria, S. (1986) 'The determination of life premiums: An international cross-section analysis 1970-1981', Insurance: Mathematics and Economics 5(4): 261-270.

Browne, M.J. and Kim, K. (1993) 'An international analysis of life insurance demand', The Journal of Risk and Insurance 60(4): 616-634.

Diacon, S.R. (1980) 'The demand for UK ordinary life insurance: 1946-1968', The Geneva Papers on Risk and Insurance Theory 17: 3-22.

Duker, J.M. (1969) 'Expenditure for life insurance among working-wife families', The Journal of Risk and Insurance 36(5): 525-533.

Farmer, R. and Mantis, G. (1968) 'Demand for life insurance', The Journal of Risk and Insurance 35(2): $247-256$

Fitzgerald, J. (1987) 'The effects of social security on life insurance demand by married couples', The Journal of Risk and Insurance 54(1): 86-99.

Fortune, P. (1973) 'A theory of optimal life insurance: Development and test', The Journal of Finance 28(3): 587-600.

Gutter, M.S. and Hatcher, Ch.B. (2008) 'Racial difference in the demand for life insurance', The Journal of Risk and Insurance 75(3): 677-689.

Hair Jr, J.F., Anderson, R.E., Tatham, R.L. and Black, W.C. (1984) Multivariate Data Analysis, Upper Saddle River, NJ: Prentice Hall, Inc. A Simon \& Schuster Company.

Hammond, J.D., Houston, D.B. and Melander, E.R. (1967) 'Determinants of household life insurance premium expenditure: An empirical investigation', The Journal of Risk and Insurance 34(3): 397-408.

Harman, H.H. (1967) Modern Factor Analysis, 2nd edn., Chicago, IL: University of Chicago Press.

Hau, A. (2000) 'Liquidity, estate liquidation, charitable motives, and life insurance demand by retired singles', The Journal of Risk and Insurance 67(1): 123-141.

Hwang, T.T. and Gao, S. (2003) 'The determinants of the demand for life insurance in an emerging economy-The case of China', Managerial Finance 29(5/6): 82-96.

Kaiser, H.F. (1974) 'An index of factorial simplicity', Psychometrika 39(1): 31-36.

Kakar, P. and Shukla, R. (2010) 'The determinants of demand for life insurance in an emerging economyIndia', The Journal of Applied Economic Research 4(1): 49-77.

Kotlikoff, L.J. and Auerbach, A.T. (1989) How rational is the purchase of life insurance? Working paper no. 3063, National Bureau of Economic Research.

Lee, C.L. and Ferber, R. (1980) 'Acquisition and accumulation of life insurance in early married life', The Journal of Risk and Insurance 47(4): 713-734.

Lee, H.C., Chen, R. and Wong, K.A. (2001) 'Age, period and cohort effects on life insurance purchases in the US', The Journal of Risk and Insurance 68(2): 303-327. 
Lee, J.F. and Headen, R.S. (1974) 'Life insurance demand and household portfolio behavior', The Journal of Risk and Insurance 41(1): 685-698.

Lewis, F.D. (1989) 'Dependents and the demand for life insurance', The American Economic Review 79(3): 452-467.

Li, D., Moshirian, F., Nguyen, P. and Wee, T. (2007) 'The demand for life insurance in OECD countries', The Journal of Risk and Insurance 74(3): 637-652.

Lin, Y. and Grace, M.F. (2007) 'Household life cycle protection: Life insurance holdings, financial vulnerability, and portfolio implications', The Journal of Risk and Insurance 74(1): 141-173.

Miller, M.A. (1985) ‘Age-related reductions in workers's life insurance', Monthly Labor Review 108(9) 29-34.

Miners, L. and Gandolfi, A.S. (1996) 'Gender-based differences in life insurance ownership', The Journal of Risk and Insurance 63(4): 686-693.

Neumann, S. (1969) 'Inflation and savings through life insurance', The Journal of Risk and Insurance 36(5): 567-582.

Nevin, J.R. and Anderson, D.R. (1975) 'Determinants of young marrieds' life insurance purchasing behavior: An empirical investigation', The Journal of Risk and Insurance 42(3): 375-387.

Outreville, J.F. (1996) 'Life insurance markets in developing countries', The Journal of Risk and Insurance 63(2): 263-278.

Palmer, B.A. and Burnett, J.J. (1984) 'Examining life insurance ownership through demographic and psychographic characteristic', The Journal of Risk and Insurance 51(3): 453-467.

Polish Insurance Chamber (2008) Insurance in 2007, Warsaw: Polish Insurance Chamber.

Rejda, G.E., Schmidt, J.R. and McNamara, M. (1987) 'The impact of social security tax contributions on group life insurance premiums', The Journal of Risk and Insurance 54(4): 712-720.

Sen, S. (2008) An analysis of life insurance demand determinants for selected Asian economies and India, Working paper 36/2008, Madres School of Economics, http://www.mse.ac.in/pub/working\%20paper\% 2036.pdf.

Showers, V.E. and Shotick, J.A. (1994) 'The effects of household characteristic on demand for insurance: A Tobit analysis', The Journal of Risk and Insurance 61(3): 492-502.

Somerville, R.A. (2004) 'Insurance, consumption, and saving: A dynamic analysis in continuous time', The American Economic Review 94(4): 1130-1140.

Tucker, L.R. (1971) 'Relations of factor score estimates to their use', Psychometrika 36(4): 427-436.

Ward, D. and Zurbruegg, R. (2002) 'Law, politics and life insurance consumption in Asia', The Geneva Papers on Risk and Insurance-Issues and Practice 27(3): 395-412.

Ward, D., Zurbruegg, R. and Hussels, S. (2005) 'Stimulating the demand for insurance', Risk Management and Insurance Review 8(2): 257-278.

Whitaker, W. and Lee, J.F. (1971) 'Competition among life products lines: Determinants of demand', Mississippi Valley Journal of Business and Economics 7(1): 23-34.

Wiliams Jr, A. (1986) 'Higher interest rates, longer lifetimes, and the demand for life annuities', The Journal of Risk and Insurance 53(1): 164-171.

Zietz, E.N. (2003) 'An examination of the demand for life insurance', Risk Management and Insurance Review 6(2): 159-191. 


\section{Appendix}

Table A1 Correlation coefficients

\begin{tabular}{|c|c|c|c|c|c|c|c|c|c|c|c|c|c|c|c|c|}
\hline & Y & $X_{1}$ & $X_{2}$ & $X_{3}$ & $X_{4}$ & $X_{5}$ & $X_{6}$ & $X_{7}$ & $X_{8}$ & $X_{9}$ & $X_{10}$ & $X_{11}$ & $X_{12}$ & $X_{13}$ & $X_{14}$ & $X_{15}$ \\
\hline$Y$ & 1 & 0.511 & 0.518 & 0.362 & -0.486 & 0.434 & -0.088 & 0.290 & -0.516 & 0.047 & -0.425 & 0.504 & -0.051 & 0.547 & 0.519 & -0.231 \\
\hline$X 1$ & 0.511 & 1 & 0.773 & 0.753 & -0.389 & -0.049 & -0.287 & 0.435 & -0.806 & 0.487 & -0.669 & 0.797 & 0.049 & 0.857 & 0.758 & -0.373 \\
\hline$X 3$ & 0.362 & 0.753 & 0.973 & 1 & -0.752 & -0.226 & -0.228 & 0.197 & -0.734 & 0.564 & -0.681 & 0.740 & -0.088 & 0.882 & 0.964 & -0.413 \\
\hline$X 4$ & -0.486 & -0.389 & -0.738 & -0.752 & 1 & 0.190 & 0.120 & 0.072 & 0.347 & -0.171 & 0.412 & -0.380 & 0.015 & -0.521 & -0.704 & 0.265 \\
\hline$X 5$ & 0.434 & -0.049 & -0.065 & -0.226 & 0.190 & 1 & 0.283 & 0.157 & -0.093 & 0.072 & 0.094 & -0.001 & 0.020 & 0.031 & -0.065 & -0.011 \\
\hline$X 6$ & -0.088 & -0.287 & -0.220 & -0.228 & 0.120 & 0.283 & 1 & -0.019 & 0.244 & 0.006 & 0.158 & -0.273 & 0.052 & -0.239 & -0.182 & 0.190 \\
\hline$X 8$ & -0.516 & -0.806 & -0.812 & -0.734 & 0.347 & -0.093 & 0.244 & -0.523 & 1 & -0.796 & 0.649 & -0.912 & 0.027 & -0.949 & -0.767 & 0.749 \\
\hline$X 9$ & 0.047 & 0.487 & 0.600 & 0.564 & -0.171 & 0.072 & 0.006 & 0.436 & -0.796 & 1 & -0.305 & 0.610 & 0.176 & 0.732 & 0.524 & -0.721 \\
\hline$X 10$ & -0.425 & -0.669 & -0.692 & -0.681 & 0.412 & 0.094 & 0.158 & -0.321 & 0.649 & -0.305 & 1 & -0.770 & 0.535 & -0.687 & -0.713 & 0.487 \\
\hline$X 11$ & 0.504 & 0.797 & 0.773 & 0.740 & -0.380 & -0.001 & -0.273 & 0.440 & -0.912 & 0.610 & -0.770 & 1 & -0.225 & 0.890 & 0.774 & -0.712 \\
\hline$X 12$ & -0.051 & 0.049 & -0.037 & -0.088 & 0.015 & 0.020 & 0.052 & 0.182 & 0.027 & 0.176 & 0.535 & -0.225 & 1 & -0.021 & -0.104 & 0.105 \\
\hline$X 13$ & 0.547 & 0.857 & 0.937 & 0.882 & -0.521 & 0.031 & -0.239 & 0.443 & -0.949 & 0.732 & -0.687 & 0.890 & -0.021 & 1 & 0.915 & -0.586 \\
\hline$X 14$ & 0.519 & 0.758 & 0.982 & 0.964 & -0.704 & -0.065 & -0.182 & 0.299 & -0.767 & 0.524 & -0.713 & 0.774 & -0.104 & 0.915 & 1 & -0.373 \\
\hline$X 15$ & -0.231 & -0.373 & -0.467 & -0.413 & 0.265 & -0.011 & 0.190 & -0.357 & 0.749 & -0.721 & 0.487 & -0.712 & 0.105 & -0.586 & -0.373 & 1 \\
\hline
\end{tabular}

Source: Authors' calculations. 


\begin{abstract}
About the Authors
Adam Sliwinski is a senior lecturer at the Warsaw School of Economics, where he received his doctoral degree in 2001. He was Postdoctoral Fellow at the University College London and Visiting Researcher at Cass Business School-City University. He has been Visiting Lecturer at Edinburgh Napier University. His main research interests are risk management and empirical aspects of finance and insurance. He has business experience cooperating with a number of international insurers.
\end{abstract}

Tomasz Michalski heads the Department of Commercial Insurance at the Warsaw School of Economics. He graduated from both the Faculty of Mathematics, Informatics and Mechanics and the Faculty of Economic Sciences of the University of Warsaw. Professor Michalski's main research areas include insurance, risk theory, mathematical models of financial area, statistical comparison analysis (taxonomy methods) as well as the European integration process. He is a member of the Polish Mathematical Society, Polish Economics Society, Polish Financial and Banking Association, International Atlantic Economic Society and Mathematical Association of America.

Malgorzata Roszkiewicz is a researcher at the Institute of Statistics and Demography at the Warsaw School of Economics. Her research activity focuses around applications of quantitative methods in the formulation of strategy and marketing policy of the companies and the demographic, social and economic determinants of economic behaviour of households. Professor Roszkiewicz is a member of the Polish Statistical Society, International Association of Survey Statisticians, European Association for Population Studies and European Society for Population Economics. 